Autor:

Fausto Pereira de Lacerda Filho

Tírulo

\title{
Cartões de Crédito - Uma introdução critica ao seu estudo
}

Banca Examinadora:

Presidente: Dr. Alfredo de Assis Gonçalves Neto

Dr. Rubens Requião

Dr. Marçal Justen Filho

Defesa: $\quad 02$ de outubro de 1989.

\section{Resumo}

Os cartões de crédito buscam incrementar as operações comerciais, oferecendo vantagens ao consumidor ávido e financeiramente tolhido, garantindo a aquisição de bens e serviços pelo preço à vista e desembolso efetivo de dinheiro em média trinta dias após a data da compra. A emissão e utilização desses cartões depende de contratos entre o emissor, o titular e o fornecedor, nascendo deles várias obrigações para as partes intervenientes. A generalidade das legislações não contempla normatização específica sobre o cartão e os sistemas que põem-no em circulação - tem de obedecer a vários critérios comuns, baseados apenas na liberdade de contratar. A dissertação expõe e explica o que são os cartões de crédito e os serviços a que se prestam, sintetizados no objetivo de facilitar a efetivação de um pagamento. O cartão uma criação empírica e um produto de importação pelo que é difícil enquadrá-lo dentro dos conceitos tradicionais do direito codificado. Ainda é um instituto em evolução que inadmite mais do que meros ensaios doutrinários a seu respeito. O trabalho foi desenvolvido em seis capítulos onde se considera: os aspectos gerais do instituto, sua qualificação jurídica, sua configuração como unidade de relações jurídicas, a forma e a interpretação do contrato de adesão pelas quais se aperfeiçoam aquelas relações, a maneira de execução do crédito com referência à jurisprudência. 